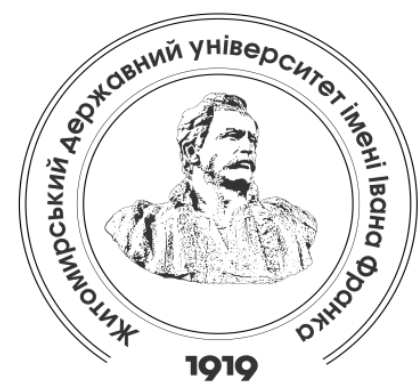

Zhytomyr Ivan Franko State University Journal. Pedagogical Sciences. Vol. 4 (99)

Вісник Житомирського державного університету імені Івана Франка.

Педагогічні науки. Вип. 4 (99)

ISSN (Print): 2663-6387

ISSN (Online): 2664-0155

\title{
UDC 811.111:373.3:316.334.23 \\ DOI 10.35433/pedagogy.4(99).2019.27-37 \\ DEVELOPING ENTREPRENEURIAL COMPETENCE IN PRIMARY SCHOOL PUPILS IN THE CONTEXT OF TEACHING ENGLISH
}

\author{
I. V. Samoylyukevych*, V. S. Kravets**
}

The research deals with the problem of the formation of entrepreneurial competence as one of the key life competences in integration with the development of communicative competence in a foreign language in primary school. Entrepreneurial competence encompasses a set of qualities, knowledge, skills, models of behaviour in different spheres of life in order to effectively address issues related to the social status of individuals, as well as the development of society and the state as a whole. The aim of the study is to identify the methodological potential for the development of entrepreneurial competence in the process of developing spoken production and spoken interaction skills in the English lessons in primary school. The research was conducted with the help of various scientific methods: theoretical analysis of psychological, pedagogical and methodological literature; methodological experiment to test the methodology suggested; methods of mathematical statistics for processing the experimental data. As a result, elements of entrepreneurial competence to be incorporated in primary school were allocated; a certain correlation was identified between the entrepreneurial skills selected and spoken interaction / spoken production skills to be developed in the process of teaching speaking to primary-school pupils in the English lessons; a system of exercises for the formation of entrepreneurial competence in primary school pupils in the process of developing spoken production and spoken interaction skills was created. The research also addresses the issues of classifying and selecting materials with entrepreneurial content as a basis for activity design within the system of exercises for the development of spoken production and spoken interaction skills in primary school pupils. The effectiveness of the proposed methodology was proven experimentally, which led us to the conclusion that the integrated approach to the development of communicative and entrepreneurial skills in primary school pupils contributed to an increase which averaged 93.9\% in the experimental group and $53.1 \%$ in the control group.

\footnotetext{
${ }^{*}$ Candidate of Pedagogical Sciences (PhD in Pedagogy), Professor (Zhytomyr Ivan Franko State University) innasamoylyukevych@gmail.com ORCID: 0000-0003-3335-1475 ${ }^{* *}$ Master Student (Primary Education) (Zhytomyr Ivan Franko State University) valeriya88810@gmail.com ORCID: 0000-0002-4265-6281
} 
Key words: entrepreneurial competence, spoken production, spoken interaction, materials with entrepreneurial content, primary school pupils, English lessons.

\section{РОЗВИТОК ПІДПРИЕМНИЦЬКОЇ КОМПЕТЕНТНОСТІ В УЧНІВ ПОЧАТКОВОЇ ШКОАИ В КОНТЕКСТІ ВИКААДАННЯ АНГАІЙСЫКОЇ МОви}

\section{I. В. Самоймюкевич, В. С. Кравець}

у дослідженні розглядається проблема фрормування підприємницької компетентності як однієї з ключових життєвих компетентностей в інтеграиї з розвитком комунікативної компетентності іноземною мовою в початковій школі. Підприємницька компетениія охоплює сукупність якостей, знань, умінь, моделей поведінки в різних сферах життя з метою ефективного вирішення питань, пов'язаних із соиіальним статусом індивідів, а також розвитком суспільства та держави в иілому. Метою дослідження $\epsilon$ виявлення методичного потениіалу розвитку підприємницької компетентності в проиесі формування умінь усного продукування та усної взаємодії на уроках англійсъкої мови в початковій школі. Дослідження проводилось за допомогою різних наукових методів: теоретичного аналізу психологічної, педагогічної та методичної літератури; методичний експеримент для перевірки запропонованої методики; методи математичної статистики для обробки експериментальних даних. Як результат, були виділені елементи підприємнииької компетентності, які слід включити до навчального проиесу у початкової освіті; виявлено певну кореляиію між обраними підприємницькими вміннями та вміннями усного продукування та усної взаємодіі, які мають бути розвинені в процесі навчання усного мовлення учнів початкових класів на уроках англійсъкої мови; створена система вправ на формування підприємницької компетентності у учнів початкових класів у проиесі розвитку вмінь усного продукування та усної взаємодії. У дослідженні також розглядаються питання класифікаиї̈ та підбору матеріалів з підприємницьким змістом як основи для проектування діяльності в рамках системи вправ на розвиток вмінь усного продукування та усної взаємодії в учнів початкових класів. Ефективність запропонованої методики було доведено експериментально, шо призвело до висновку, шо комплексний підхід до розвитку комунікативних та підприємницьких навичок у учнів початкових класів сприяв збільшенню показників сформованості підприємницьких умінь, яке в середньому склало 93,9\% в експериментальній групі та 53, 1\% у контрольній групі.

Ключові слова: підприємнииька компетентність, усне продукування, усна взаємодія, матеріали з підприємницьким змістом, учні початкових класів, уроки англійської мови

Introduction of the issue. The current stage of social development is characterized by the processes of globalization and integration in different spheres of life. All advanced nations need citizens who are quickly able to adapt to the changing world. Hence, there is a need for a wide range of key life competencies specified in the Recommendations of the European Parliament and of the Council of Europe (18 December 2006).
For Ukraine, which is currently being in an unfavorable economic situation, it is necessary to create a society that would bring it out of crisis. Since society is made up of individuals, it may only be made possible by forming in each person the appropriate competencies and personality traits so that we could achieve the proper level of development. Entrepreneurship as one of the key life competences to be 
incorporated in the New Ukrainian School means the ability of a person to bring to life new ideas and initiatives, as well as to creatively approach problem solving, innovate, plan activities and take healthy risks.

Entrepreneurial competence is also characterized by proactivity, independence and innovation in both personal and social life in today's multicultural and mobile world. Therefore, modern school graduates should be individuals who are able to actively interact with the outside world and other cultures, analyzing their experience in social and economic development to reform their state and society. This indicates the necessity for a good command of foreign languages, primarily of English as a global language, to be an important prerequisite for all international entrepreneurial contacts.

Today, foreign language learning and teaching begins quite early - in preschool and primary education - and faces the challenges of shifting from theory to more practical life-based applications which are reflected in the requirements of the State Standards in Primary Education [5] and the foreign language curriculum. Therefore, in our opinion, it is the integration of elements of entrepreneurial competence in the educational process in the primary English language classroom that can help meet these challenges.

Current state of the issue. The issues of the formation of entrepreneurial competence in the educational process was considered by a number of foreign and Ukrainian scholars: E. Bobinska (the role of interactive methods in the formation of learners' entrepreneurial competence),

A. Helbak (the development of entrepreneurship and financial literacy in high school students [6]), K. Koshevskaya (the structure of entrepreneurial competence [4: 22]),
G. Nazarenko (entrepreneurship as a way of the formation of knowledge economy in Ukraine), S. Prishchepa (contemporary approaches to the formation of entrepreneurial competence in primary school learners), M. Tovkalo (ways of creating an entrepreneurial context of the lesson [4: 32]), I. Unguryan (innovative techniques for developing entrepreneurship), R. Shiyan (the role of self-development for a prospective entrepreneur [4: 18]) and others.

The outline of unresolved issues brought up in the article. In general terms, different aspects of the formation of entrepreneurial competence are considered in detail. In this article, the previous research is expanded to particular issues of incorporating elements of entrepreneurial competence in the context of teaching English in primary school.

Aim of research is to identify the methodological potential for the development of entrepreneurial competence in the process of teaching spoken production and spoken interaction in the English lessons in primary school.

The objectives of the study are as follows: 1) to allocate the elements of entrepreneurial competence to be incorporated in primary school; 2) to identify a correlation between the entrepreneurial skills selected and spoken interaction / spoken production skills to be developed in the process of teaching speaking to primary-school pupils in the English lessons; 3) to create a system of exercises for the formation of entrepreneurial competence in primary school pupils in the process of developing spoken production and spoken interaction skills and to experimentally check the effectiveness of the proposed methodology.

The research used the following methods: theoretical analysis of 
psychological, pedagogical and methodological literature in order to identify the potential for the development of entrepreneurial competence in the process of teaching spoken production and spoken interaction in the English lessons in primary school; methodological experiment to test the methodology suggested; methods of mathematical statistics for processing the experimental data.

Results and discussion. Having conducted the content analysis of the concept of "entrepreneurial competence", we have found out that the scholars who researched the problem of the formation of entrepreneurial competence disagree in the interpretation of this concept. The highest percentage of researchers $(22.22 \%)$ consider entrepreneurial competence to be a set of qualities, skills, knowledge, a certain model of behaviour, which help to solve professional and everyday tasks. Such an interpretation is favoured by domestic scholars (S. Prishchepa, M. Strelnikov, O. Liskovich) and foreign ones (O. Novozhen, N. Birnaz, A. Myritska, D. Meshcheryakov). The second place $(18.5 \%)$ was taken by the researchers who interpreted entrepreneurial competence as the ability to recognize and anticipate, translate new ideas into different spheres of life (M. Tkachenko, V. Wong, T. Mann, T. Lau, T. Erickson and others). It should be noted that the document of the Council of Europe "Key Competences for Lifelong Learning: A European Reference Framework" also sees entrepreneurial competence as an individual's ability to translate ideas into economic life, as an integrated quality based on creativity, creativity, innovation, risktaking, and the ability to plan and to organize business activities [7]. $7.4 \%$ of the scientific works analyzed present entrepreneurial competence as an integral psychological quality as well as individual characteristics of an entrepreneur. For example, B. Bird believes that entrepreneurial competence is based on characteristics such as specific knowledge, motives, traits, self-images, social roles and skills that lead to birth, survival and/or growth [3]. 3.7\% of authors' opinions were divided between explanations of the concept of "entrepreneurial competence" as a process that involves the acquisition of entrepreneurial knowledge by a person, a certain characteristic of a person, personal property, specific behaviors, a component of professional competence, etc. Each of them has the right to exist.

Having analysed the views of various scholars on the concept of entrepreneurial competence, we understand it as a set of qualities, knowledge, skills, models of behaviour in different spheres of life in order to effectively address issues related to the social status of individuals, as well as the development of society and the state as a whole.

The problem of the formation of entrepreneurial competence in education is relatively new to the Ukrainian educational context. In developed countries, entrepreneurship has long been regarded as an integral part of the educational process.

According to the Entrepreneurial Competence Framework, the structure of entrepreneurial competence includes the following content areas and their corresponding skills: 1) content area 'Ideas and Opportunities': identifying opportunities; creativity; vision; evaluation of ideas; ethical and sound thinking; 2) content area 'Resources': self-awareness and self-efficacy, motivation and perseverance, resource mobilization, financial and economic literacy, mobilization of others; 3) content area 'Transformation in action': taking the initiative, planning 
and management, dealing with ambiguity, uncertainty and risks; cooperation with others; learning through experience [1: 11].

In order to develop an effective methodology for the formation of entrepreneurial competence in primary school pupils, it is necessary to establish a correlation between the age-specific psychological characteristics of primary-school children and the components of entrepreneurial competence. To do this task, the following works have been analyzed: P. Blonsky (features of memory development), L. Vygotsky (concepts of development of higher mental functions, speech thinking), D. Elkonin (educational motivation), V. Zinchenko (involuntary memorization), G. Kostyuk (connection of psychology with pedagogy), O. Leontiev (problems of consciousness and activity), J. William (consciousness as an instrument of biological adaptation of the individual), A. Zelts (determination though processes) and others.

Taking into account age-specific psychological characteristics of primary-school pupils, we have identified those that are likely to contribute to the formation of the relevant components of entrepreneurial competence specified in EntreComp [1]. For example, developed imagination and fantasy contribute to the formation of creativity; the development of social motives for learning - to motivation and persistence; brightness and brightness development and increase of the share of verbal-logical memory - to financial and economic literacy; immediacy - to taking initiative, suggestiveness; aesthetic attitude to the environment to planning and management, the close connection of perception to practical activities - to learning through experience.

In order to trace an interrelation between the entrepreneurial skills selected, on the one hand, and spoken interaction/spoken production skills, on the other, we have analyzed the repertoire of speech skills for each form of speaking described by Prof. S. Nikolaieva [2]. As a result, the following correlation between the entrepreneurial skills selected and spoken interaction / spoken production skills was established (see Tab. 1).

Correlation between the entrepreneurial skills and spoken interaction / spoken production skills

\begin{tabular}{|c|c|c|}
\hline $\begin{array}{c}\text { Entrepreneurial skills } \\
\text { (according to EntreComp) }\end{array}$ & $\begin{array}{c}\text { Spoken interaction } \\
\text { skills }\end{array}$ & Spoken production skills \\
\hline Creativity & $\begin{array}{c}\text { Ability to expand the topic } \\
\text { of a conversation offered } \\
\text { by the interlocutor, ability } \\
\text { to move to another topic }\end{array}$ & $\begin{array}{c}\text { Ability to engage in the } \\
\text { presentation of a particular } \\
\text { topic material related topics, } \\
\text { expanding and deepening it, } \\
\text { combining and varying } \\
\text { material in form and content }\end{array}$ \\
\hline $\begin{array}{c}\text { Motivation and } \\
\text { perseverance }\end{array}$ & $\begin{array}{c}\text { Ability to talk to one or } \\
\text { more persons according to } \\
\text { the communicative } \\
\text { situation within the topics } \\
\text { defined by the program }\end{array}$ & $\begin{array}{c}\text { Ability to express one's own } \\
\text { opinion and one's own } \\
\text { attitude to the subject of } \\
\text { speech }\end{array}$ \\
\hline $\begin{array}{c}\text { Mobilisation of other } \\
\text { persons for the purpose } \\
\text { of cooperation }\end{array}$ & $\begin{array}{c}\text { Ability to request } \\
\text { information }\end{array}$ & $\begin{array}{c}\text { Ability to seek help from an } \\
\text { audience }\end{array}$ \\
\hline
\end{tabular}


Вісник Житомирсъкого державного иніверситети імені Івана Франка. Педагогічні науки. Bun. 4 (99)

\begin{tabular}{|c|c|c|}
\hline $\begin{array}{c}\text { Fundamentals of } \\
\text { Financial and Economic } \\
\text { Literacy }\end{array}$ & $\begin{array}{c}\text { Ability to classify, } \\
\text { systematize and critically } \\
\text { evaluate and respond to } \\
\text { information received in } \\
\text { the communication } \\
\text { process }\end{array}$ & $\begin{array}{c}\text { Ability to combine speech } \\
\text { patterns according to } \\
\text { communicative intent and } \\
\text { based on logic }\end{array}$ \\
\hline Taking the initiative & $\begin{array}{c}\text { Ability to initiate and end } \\
\text { conversation }\end{array}$ & $\begin{array}{c}\text { Ability to speak fully in } \\
\text { accordance with the } \\
\text { proposed communicative } \\
\text { situation }\end{array}$ \\
\hline $\begin{array}{c}\text { Planning and } \\
\text { management }\end{array}$ & $\begin{array}{c}\text { Ability to anticipate and } \\
\text { plan your speech activity }\end{array}$ & $\begin{array}{c}\text { Ability to plan and program } \\
\text { speech utterances }\end{array}$ \\
\hline Aearning through & $\begin{array}{c}\text { Ability to adequately } \\
\text { behave in communicative } \\
\text { situations by displaying } \\
\text { speech behavior } \\
\text { characteristic of native } \\
\text { speakers }\end{array}$ & $\begin{array}{c}\text { Ability to optimally use the } \\
\text { previously learned material } \\
\text { of the topic, consciously } \\
\text { transferring the acquired } \\
\text { knowledge, skills, skills to a } \\
\text { new situation }\end{array}$ \\
\hline
\end{tabular}

The next task of our research deals with the activities, materials, and stages of the formation of entrepreneurial competence in primary school pupils in the process of developing spoken production and spoken interaction skills in the English lessons. The results of the activity and material design were arranged in a scientifically grounded system of exercises based on the usage of specially selected materials with entrepreneurial content.

The selection of materials with entrepreneurial content was based on three criteria: the degree of authenticity, relevance to the topics under study, and the type of visuality. Thus, we have differentiated between; ELT (English Language Teaching) materials and non-ELT materials; thematic and cross-thematic materials; oral/optic verbal, non-verbal and mixed visuality. Importantly, all the materials selected were to meet the following requirements: they should be agespecific, motivational, and interactive.

The methodology per se consisted of two subsystems: subsystem A (exercises for the formation of entrepreneurial competence in the process of developing spoken production skills) and subsystem B (exercises for the formation of entrepreneurial competence in the process of developing spoken interaction skills). Each subsystem is realized through four stages.

At the 1st, preparatory stage, learners are offered receptive exercises aimed at processing information from texts with entrepreneurial content. Below is a sample activity for teaching pupils to extract necessary information from a text with entrepreneurial content (content area 'Resources', ELT materials of thematic character, oral verbal visuality).

Instruction 1: Listen and choose the cheapest food.

Audiotext: Oksana's mother is going to the grocery store. She plans to buy a pack of butter. It costs 28 hryvnias. She also wants to buy some apples. They cost 18 hryvnias. Instead, the mother buys some oranges. They cost 20 hryvnias. Then she buys some flour. It costs 19 hryvnias. Oksana's mother is going to make a tasty pie at home.

Key: apples.

The 2nd, controlled practice stage, provides reproductive exercises based on formulated information or a text fragment with entrepreneurial content, 
in which learners are to combine various speech-patterns into an utterance (to develop spoken production skills) or to combine adjacency pairs into a micro-dialogue (to develop spoken interaction skills). For example, the reproductive activity below is aimed at the formation of entrepreneurial skills in the content

1

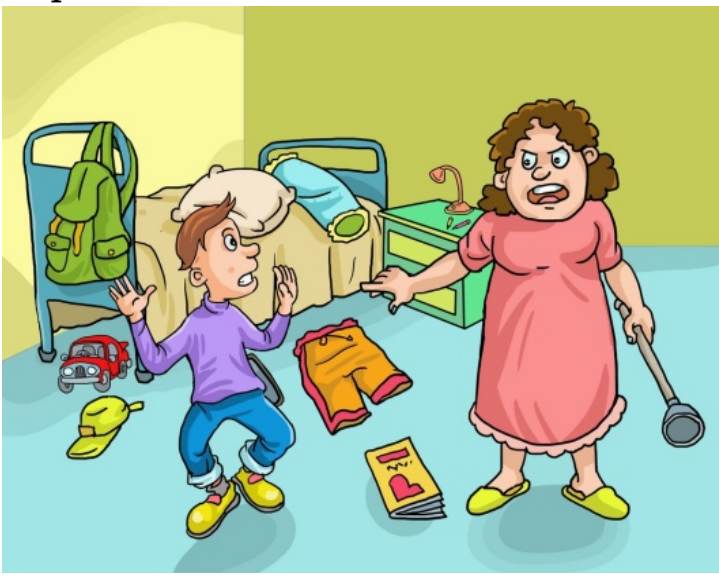

1) The mother is happy.

2) The mother is very angry.

3) The boy is afraid of his mother.

4) The room is in disorder.

5) The girl is helping her mother to cook.

6) Her son is a lazy child.

7) Her daughter is a hard-working child.

Key: Picture One - 2), 3), 4), 6); Picture Two - 1), 5), 7).

The 3d, guided practice stage, presupposes doing reproductive-andproductive exercises on an utterance level or a micro-dialogue level where learners are given non-verbal props with entrepreneurial content. Here is a sample activity for the content area 'Resources' in which learners have to complete the text and explain how they come up with their ideas; the materials to support the activity include a gapped printed text, a picture and mathematical tasks.

Instruction 3: Count, color and say how much all their clothes cost. area 'Transformation in action' and teaching pupils to combine speechpatterns into an utterance; it is based on ELT materials of thematic character (mixed visuality).

Instruction 2: Choose the right sentences for the pictures and describe the situations.
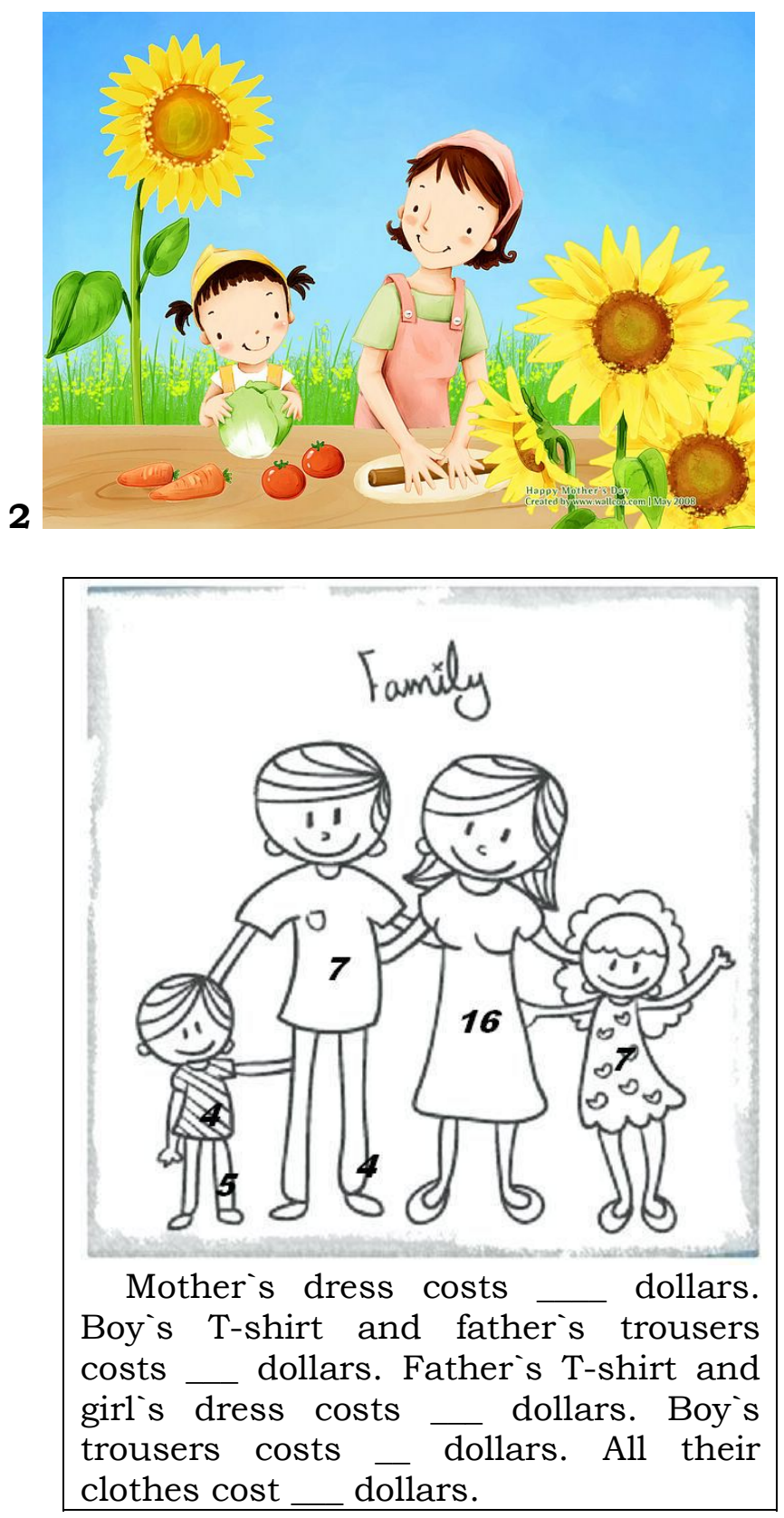

1. $5+2-3=$ (зелений)

2. $8+10-2=$ — (червоний)

3. $5+6-4=-$ (блакитний)

4. $3-1+3=\square$ (коричневий) 
At the 4th, free production / interaction stage, productive exercises are stimulated by creative communicative tasks and/or situations and done at a text level. The following is a productive activity in which learners create and present their own daily menu, thus developing their entrepreneurial skills in the content area 'Ideas and opportunities' as well as their spoken production skills.

Instruction: Make paper plates of your breakfast, dinner and breakfast. Present them to your classmates.

In order to check the effectiveness of the methodology suggested, a methodological experiment was conducted in the natural learning environment, which involved 32 participants (16 of them were $3 d$ grade pupils in the experimental group (EG) and 16 more 3d-graders were the control group (CG). The experiment was carried out in the English lessons while processing two thematic units in a sequence that corresponds to the syllabus. Each thematic cycle [7] was based on the sets of exercises designed in accordance with two subsystems to form the specified competence.

To calculate the learning coefficient for each individual control entity by V. Bezpalko, we used the formula:

$$
K=\frac{Q}{N}
$$

where $\mathrm{K}$ is the learning coefficient; $\mathrm{Q}$ is an indicator of the corresponding coefficient; $\mathrm{N}$ is the maximum index of the corresponding coefficient. Following V. Bezpalko, we consider a sufficient level of the formation of relevant skills to be the indicator of the learning coefficient that is greater than or equal to 0.7.

At the beginning of the methodological experiment, a preexperimental testing was held in order to determine the initial level of entrepreneurial competence of primary school pupils in the process of developing spoken production and spoken interaction skills.

The results of the pre-experimental testing in the experimental and control groups are presented in Tab. 2.

Table 2

Average indicators of the level of the formation of entrepreneurial competence of primary school pupils in the process of teaching spoken production / spoken interaction (the results of pre-experimental testing)

\begin{tabular}{|c|c|c|c|c|c|}
\hline \multirow[b]{2}{*}{ Group } & \multicolumn{3}{|c|}{$\begin{array}{c}\text { Indicators by criteria of estimation of level } \\
\text { of formation of entrepreneurial } \\
\text { competence, average scores (average } \\
\text { learning coefficient) }\end{array}$} & \multicolumn{2}{|c|}{$\begin{array}{c}\text { By all } \\
\text { the criteria }\end{array}$} \\
\hline & 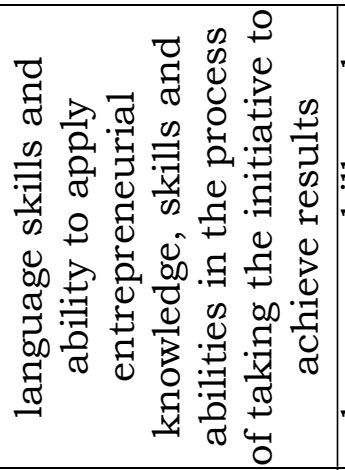 & 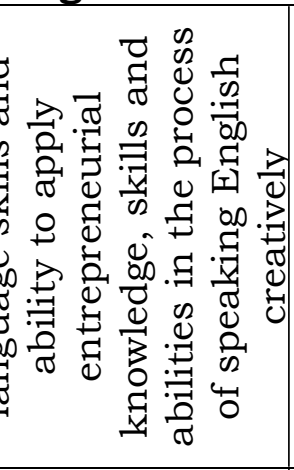 & 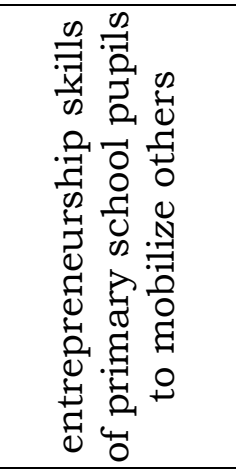 & 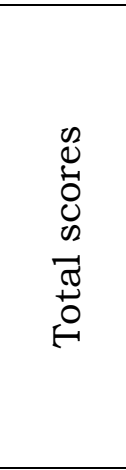 & 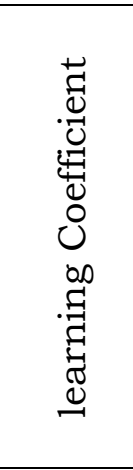 \\
\hline EG & $11(0,37)$ & $4,35(0,48)$ & $2,45(0,40)$ & 17,8 & 0,395 \\
\hline $\mathbf{C G}$ & $11,75(0,39)$ & $5,35(0,59)$ & $3,35(0,56)$ & 20,45 & 0,454 \\
\hline $\begin{array}{l}\text { Maximum } \\
\text { scores }\end{array}$ & $30(1)$ & $9(1)$ & $6(1)$ & 45 & 1 \\
\hline
\end{tabular}


In general, the average learning coefficient in CG was 0.454 , in EG 0.395 . These results indicate a lack of entrepreneurial competence in primary school students in the experimental and control groups. In our opinion, this is due to the lack of systematic and purposeful work on applying integrated tasks aimed at developing entrepreneurial knowledge and skills in the English language learning process.
The final stage of the experimental work was the post-experimental testing, the task of which was to determine the final level of the formation of entrepreneurial competence in primary school pupils in the process of developing spoken production and spoken interaction skills in the English lessons. The results of the post-experimental testing are presented below (see Tab. 3).

\section{Average indicators of the level of the formation of entrepreneurial competence of primary school pupils in the process of developing spoken production / spoken interaction skills (the results of post-experimental testing)}

\begin{tabular}{|c|c|c|c|c|c|}
\hline \multirow[b]{2}{*}{ Group } & \multicolumn{3}{|c|}{$\begin{array}{l}\text { Indicators by criteria of estimation of level of } \\
\text { formation of entrepreneurial competence, } \\
\text { average scores (average learning coefficient) }\end{array}$} & \multicolumn{2}{|c|}{$\begin{array}{c}\text { By all } \\
\text { the criteria }\end{array}$} \\
\hline & 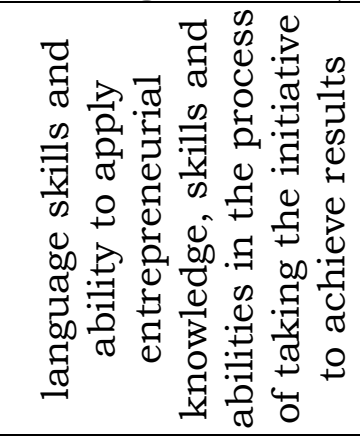 & 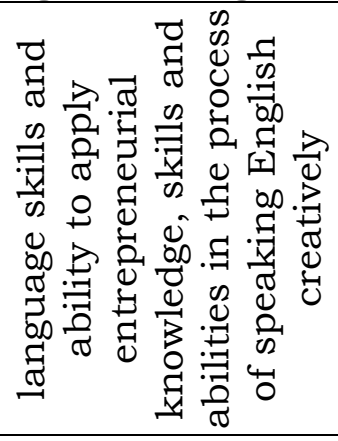 & 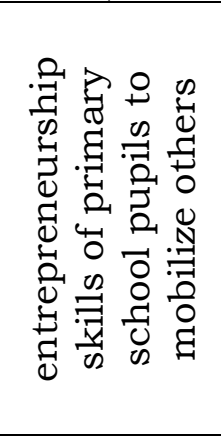 & 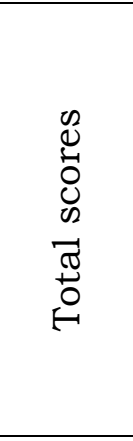 & 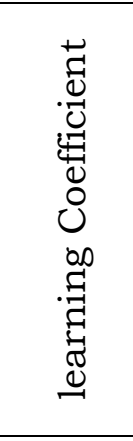 \\
\hline EG & $23,27(0,77)$ & $6,86(0,76)$ & $4,35(0,72)$ & 34,48 & 0,766 \\
\hline CG & $13,83(0,46)$ & $6(0,67)$ & $4,1(0,68)$ & 23,93 & 0,532 \\
\hline $\begin{array}{l}\text { Maximum } \\
\text { scores }\end{array}$ & $30(1)$ & $9(1)$ & $6(1)$ & 45 & 1 \\
\hline
\end{tabular}

In general, the participants had a higher increase in EG - 93.9\% (p $<0.001$ ), respectively, and in the CG group in which training was carried out according to the national curriculum $17.2 \%(\mathrm{p}<0.001)$. The average learning ratio of both groups increased by $55.55 \%$.

Completing the comparative analysis of the data obtained at the preexperimental and post-experimental stages, we present the results in the form of a diagram (see Fig. 1). 


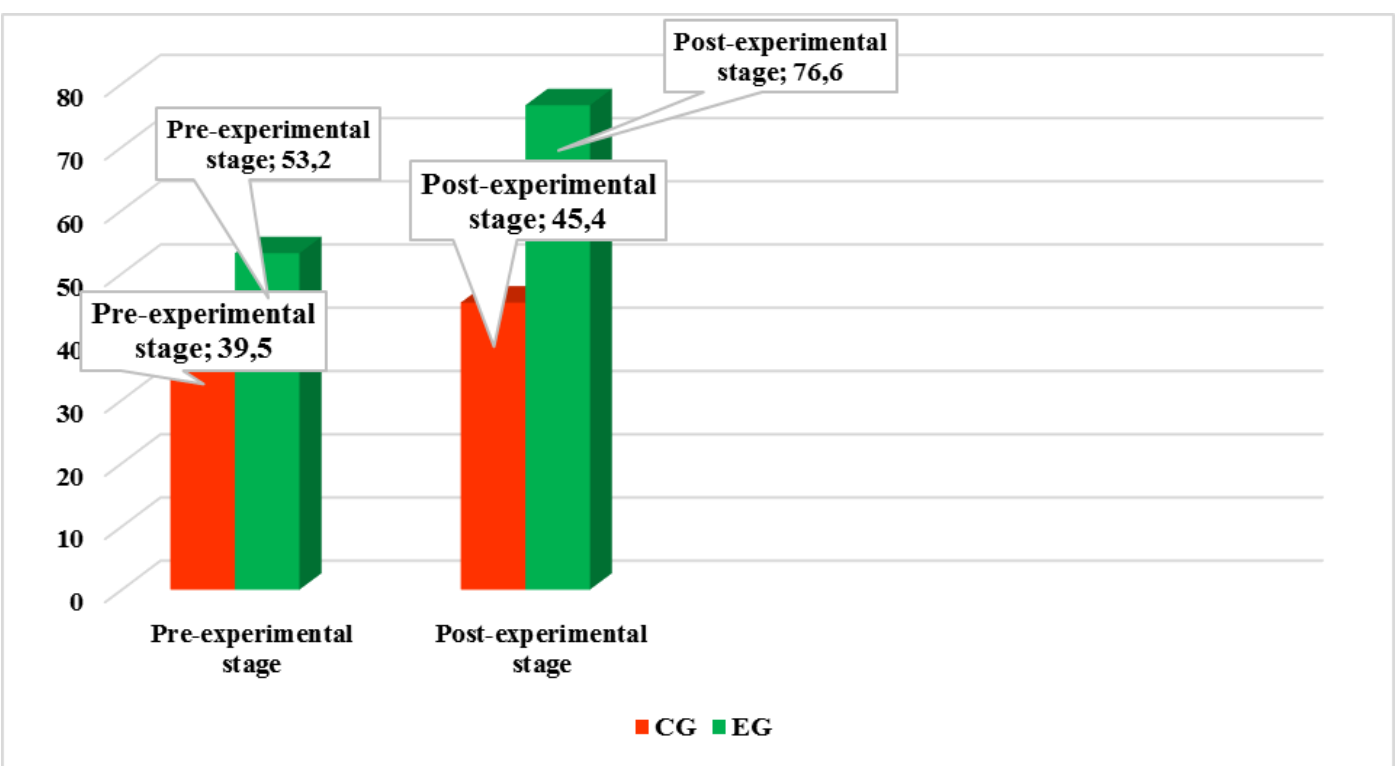

Fig. 1. The average levels of the formation of entrepreneurial competence of primary school pupils in the process of developing spoken production / spoken interaction skills in the English lessons.

Summarising the results, it can be noted that the integrated approach to the development of communicative and entrepreneurial skills in primary school pupils contributed to an increase which averaged $93.9 \%$ in the EG and $53.1 \%$ in the CG. Given the higher rates of growth in EG, there are grounds to state the effectiveness of the elaborated methodology for the formation of entrepreneurial competence in primary school pupils in the process of developing spoken production and spoken interaction skills in the English lessons.

Conclusions and research perspectives. The article deals with the topical problem of the formation of key life competences, in particular, entrepreneurial competence, in integration with the development of communicative competence in primary school. In addition, the identification of the correlation between the age-specific psychological characteristics of primary-school children and the components of entrepreneurial competence made it possible to incorporate the selected entrepreneurial skills in the process of developing speaking skills in the English lessons. The research also addresses the issues of classifying and selecting materials with entrepreneurial content as a basis for activity design within the system of exercises for the development of spoken production and spoken interaction skills in primary school pupils.

The perspectives for further research lie in the identification of pedagogical prerequisites for developing prospective primary school teachers' readiness for the formation of entrepreneurial skills in their pupils, the reconceptualisation of particular themes in the ELT Methodology curriculum within the framework of the integrated approach to teaching a foreign language in a more practical, life-based way.

\section{REFERENCES (TRANSLATED \& TRANSLITERATED)}

1. Bacigalupo, M., Kampylis, P., Punie, Y., Van den Brande, G. (2016). EntreComp: The Entrepreneurship Competence Framework. Luxenburg: Publication Office of the European Union [in English].

2. Bihych, O.B., Borysko, N.F., Boretska, H.E. et al. (2013). Metodyka 
navchannia inozemnykh mov ta kultur: teoriia i praktyka [Methods of Teaching Foreign Languages and Cultures: Theory and Practice]. S.Yu. Nikolaieva (Ed.). Kyiv: Lenvit [in Ukrainian].

3. Bird, B. (1995). Towards a theory of entrepreneurial competency. Advances in Entrepreneurship, Firm Emergence and Growth, 2, 51-72 [in English].

4. Bobinska E., Shyian R., Tovkalo M. (Eds.). (2014). Uroky $z$ pidpryiemnytskym tlom [Lessons with an Entrepreneurial Background]. Varshava, Polshcha: Sova [in Ukrainian].

5. Derzhavnyi standart pochatkovoi osvity [State Standard of Primary Education]. (n.d.). Retrieved from https://ru.osvita.ua/legislation/Ser_os v/59891/ [in Ukrainian].

6. Helbak, A.M.

Formuvannia pidpryiemlyvosti uchnia yak kliuchovoi kompetentnosti dlia zhyttia [Forming Entrepreneurship in Student as a Key Competency for Life]. Kropyvnytskyi: KZ "KOIPPO imeni Vasylia Sukhomlynskoho" [in Ukrainian].

7. Inozemni movy. Navchalni prohramy dlia 1-4 klasiv zahalnoosvitnikh navchalnykh zakladiv ta spetsializovanykh shkil [Foreign languages. Curriculums for 1-4 classes of secondary schools and specialized schools]. (n.d.). Retrieved from http://mon.gov.ua/activity/education/ zagalna-serednya/pochatkovashkola.html [in Ukrainian].

8. Key Competences for Lifelong Learning. A European Reference Framework (n.d.). Retrieved from https://www.britishcouncil.org/sites/d efault/files/youth-in-action-keycompen.pdf [in English].

Received: October 30, 2019 Accepted: November 15, 2019 